\title{
Evolution of rifted continental margins: The case of the Gulf of Lions (Western Mediterranean Basin)
}

\author{
François Bache ${ }^{\text {a, b, c, d, e, }{ }^{*} \text {, Jean Louis Olivet }}{ }^{\mathrm{a}}$, Christian Gorini ${ }^{\mathrm{d}, \mathrm{e}}$, Daniel Aslanian ${ }^{\mathrm{a}}$, Cinthia \\ Labails $^{f}$ and Marina Rabineau ${ }^{\mathrm{b}, \mathrm{c}}$
}

\author{
a IFREMER, Géosciences Marines, LGG, BP70, 29280 Plouzané cédex, France \\ ${ }^{b}$ Université Européenne de Bretagne, Brest, France \\ c Université de Brest, CNRS, IUEM, Domaines Océaniques-UMR 6538, Place N. Copernic, F-29280 Plouzané, \\ France \\ d UPMC Univ. Paris 06, UMR 7193, ISTEP, F-75005, Paris, France \\ e CNRS, UMR 7193, ISTEP, F-75005, Paris, France \\ f Center for Geodynamics, NGU-Geological Survey of Norway, Leiv. Eirikssons vei 39, N-7491 Trondheim, \\ Norway
}

*: Corresponding author : francois.bache@upmc.fr

\begin{abstract}
:
The formation of rifted continental margins has long been explained by numerous physical models. However, field observations are still lacking to validate or constrain these models. This study presents major new observations on the broad continental margin of the Gulf of Lions, based on a large amount of varied data. Two contrasting regions characterize the thinned continental crust of this margin. One of these regions corresponds to a narrow rift zone $(40-50 \mathrm{~km}$ wide) that was highly thinned and stretched during rifting. In contrast with this domain, a large part of the margin subsided slowly during rifting and then rapidly after rifting. The thinning of this domain cannot be explained by stretching of the upper crust. We can thus recognize a zonation of the stretching in both time and space. In addition, the Provencal Basin is characterized by a segmentation of the order of $100-150 \mathrm{~km}$. These observations have important consequences on the formation and evolution of the Gulf of Lions margin. Independently of the geodynamic context, we can propose some general features that characterize the formation of rifted continental margins.
\end{abstract}

Keywords: subsidence; passive margins; back-arc; rifting; erosion; stretching; thinning; Western Mediterranean; Gulf of Lions 


\section{Introduction}

The formation of continental margins and rift basins is classically explained by lithospheric extension. Mc Kenzie (1978) quantified the vertical motions that result from a uniform and passive extension of the crust and lithosphere. The two main contributions to these motions are subsidence, caused by crustal thinning, and uplift, caused by lithosphere heating. The combination of these two factors explains an initial rapid subsidence during rifting, followed by a slower thermal subsidence after rifting as the lithosphere cools down and returns to its original thickness. However, this pattern is not always observed on continental margins. For example, studies have demonstrated a rift-flank uplift of up to $1000 \mathrm{~m}$ in the Gulf of Suez (Steckler, 1985) or uplift and erosion landward of a narrow hinge zone in the US Atlantic and eastern Australian continental margins (Weissel and Karner, 1984; Steckler et al., 1988). A greater degree of extension at depth rather than in the upper crust has been proposed to account for these observations (Royden and Keen, 1980; Steckler, 1985; Steckler et al., 1988; Davis and Kusznir, 2004; Reston, 2007; Huismans and Beaumont, 2008). Recent studies on different margins allow us to compare the observations of late synrift sediments deposited under shallow-water conditions offshore from the hinge zone to the oceanic domain (Moulin et al., 2005; Dupré et al., 2007; Péron-Pinvidic and Manatschal, 2008; Aslanian et al., 2009; Labails et al., 2009). However, the great diversity of margin morphologies leads us to consider firstly the influence of the local geodynamic context (included inheritance) before proposing general dynamic models of lithospheric extension. Unfortunately, this task is made more difficult by the long and complex pre-rift history, often combined with poor-quality and scattered geophysical and subsurface data. This last point has been repeatedly emphasized by Watts (1981): "unfortunately, there is presently too little seismic and lithologic information on the actual proportion of pre-rift and syn-rift to post-rift sediments (...) to constrain these models". 
This study presents the young and weakly deformed Gulf of Lions continental margin, which is covered by a dense network of observations. These data lead to a new model for the formation of this margin and allow us to identify some major characteristics that can be compared with observations made on other rifted continental margins.

\section{Geodynamic context and subsidence studies in the Gulf of Lions}

\subsection{The basin and its margins}

In the western Mediterranean, the Provencal Basin is a young oceanic basin created by a Miocene counter-clockwise rotation of Corsica-Sardinian micro-plate (Smith, 1971; Auzende et al., 1973; Dewey et al., 1973; Olivet, 1996; Gueguen et al., 1998; Gattacceca et al., 2007). Along the north-western edge of this basin, the broad Gulf of Lions margin is bordered on either side by the narrow Provence and Catalonian margins. On the south-eastern conjugate edge, the broad Sardinian margin is intercalated between the narrow Nurra and Iglesiente margins. In this way, the Provencal Basin is characterized by a segmentation of the order of 100-150 km (Fig. 1).

The central part of the Provencal Basin shows magnetic anomalies and velocities related to the presence of a typical oceanic crust (Le Douaran et al., 1984; De Voogd et al., 1991; Pascal et al., 1993). This central oceanic domain (Fig. 1) is separated from the continental margins by two domains of unknown nature without magnetic anomalies (or with low-amplitude anomalies). These transitional domains appear to be an equivalent of the Ocean-Continent Transition (OCT) as described on the Galicia margin (Boillot et al., 1980).

The opening of the Provencal Basin, followed by the Tyrrhenian Sea, took place in the backarc region of the south-eastward retreating Apennines-Maghrebides subduction zone (Réhault et al., 1984; Malinverno and Ryan, 1986; Jolivet and Faccenna, 2000). Furthermore, the Gulf of Lions is located at the eastern end of the Pyrenees and the southern end of the West European Rift system (Rhine Graben, Bresse, Fig. 1). This margin is therefore the result of a 
complex but well-known tectonic evolution (see (Gorini et al., 1993; Séranne, 1999; Guennoc et al., 2000) for reviews).

\subsection{Pyrenean inheritance}

The Pyrenean orogeny affects the northern boundaries of the Iberian plate (Pyrenees) and the Corsica-Sardinia plate (Languedoc-Provence) at the end of the Eocene (Arthaud and Séguret, 1981). In the Pyrenees, a shortening of $100 \mathrm{~km}$ or $150 \mathrm{~km}$ has been estimated, respectively, by an analysis of the Ecors seismic profile (Roure et al., 1989) and by kinematic studies (Sibuet and Collette, 1991; Olivet, 1996). Eastward of the Pyrenees, in the Languedoc-Provence domain, various authors have estimated a shortening of the order of $50 \mathrm{~km}$ (Arthaud and Séguret, 1981; Guieu and Roussel, 1990). Moreover, no deformation linked with this phase has been reported in Corsica-Sardinia. NE-SW-trending Variscan and Tethyan structural directions are preserved in the Gulf of Lions, thus corroborating these differences of shortening. One important consequence is the activation of a major N-S strike-slip fault between the Iberian and Corsica-Sardinia plates during the Late Cretaceous-Late Eocene (Olivet, 1996). The Catalan and Igleziente margins seem to be directly related to this strike slip fault (Chapter 5.1).

\subsection{Age of rifting}

At the end of the Eocene (Priabonian), the West European Rift system developed first in the Rhine Graben, and then toward the south in the areas of Bresse and Valence. Séranne (1999) has suggested an incipient structural development of the Camargue Basin during the West European Rift phase. In the Gulf of Lions, the onset of rifting is attributed to the Oligocene, contemporaneous with intraplate alkalic volcanism in Languedoc and andesitic volcanism (related to the Apennines-Maghrebides subduction) in western Sardinia and offshore western Corsica (Boccaletti and Guazzone, 1974; Gennessaux et al., 1974; Bellaiche et al., 1979; 
116 Réhault et al., 1984). The end of the rifting is dated at between 23 and 19 Ma according to

117 numerous authors (Edel, 1980; Réhault et al., 1984; Ferrandini et al., 2003; Gattacceca et al., 118 2007). The rifting of the Gulf of Lions is thus very short-lived ( $\sim 9 \mathrm{Ma})$ in comparison to the

119 duration for other margins in extension (i.e., 10-160 Myr), which chiefly depends on the

120 interaction between lithospheric plates (Ziegler and Cloetingh, 2004).

121

\subsection{Subsidence of the basin}

In terms of subsidence, the Provencal basin has long been considered as an Atlantic-type passive margin (Ryan, 1976; Steckler and Watts, 1980; Burrus, 1989). While uniform extension models (McKenzie, 1978) were largely used to explain the evolution of such margins, many discrepancies with the predictions of these models have been highlighted in the Gulf of Lions. Steckler and Watts (1980) used biostratigraphic data from commercial wells to study the subsidence history of the Gulf of Lions. They described a relatively small volume of syn-rift sediments compared to post-rift sediments. For these authors, the small amount of subsidence associated with rifting rules out any major stretching of the continental crust, while the magnitude of the thermal subsidence requires widespread heating of thelithosphere during rifting. Steckler and Watts (1980) concluded that mechanisms other than passive heating related to stretching are required to account fully for these observations. This first type of discrepancy was not corroborated by more recent studies, which described a great thickness of synrift sediments (Bessis, 1986; Guennoc et al., 2000). Bessis (1986) and Burrus (1989) pointed out that the evolution of the subsidence of the Gulf of Lions was qualitatively (rapid initial subsidence during rifting, followed by a slower thermal subsidence after rifting) but not quantitatively in agreement with the uniform stretching model proposed by McKenzie (1978). In this way, they introduced the concept of "paradox of stretching" in the Gulf of Lions: the high values of stretching required are inconsistent with the crustal thinning ratio inferred from observations of the structural geology. For these latter authors 
143 (op. cit.), stretching plays only a minor role and some other mechanisms appear to be

144 responsible for most of the crustal thinning. The discrepancy between observations and the 145 predictions of uniform extension models casts doubt on the validity of comparing the Gulf of

146 Lions margin to an Atlantic-type passive margin (assuming that uniform extension models

147 can be applied to Atlantic-type passive margins). Hence, various authors proposed an

148 influence due to the eastward retreat and roll-back of the Apennines-Maghrebides slab

149 (Faccenna et al., 2001; Jolivet et al., 2008; Yamasaki and Stephenson, 2008) and/or the

150 overthrusting of the Pyrenean Eocene units (Séranne, 1999).

151

152

153

154

155

\section{Data}

This study benefited from large amount of data collected in the area for both commercial and academic purposes (Fig. 1). A partnership with Total gave us access a complete set of conventional and high-resolution seismic reflection data from the coast to the deep sea domain. Seismic interpretations were carried out based on the principles of seismic stratigraphy (Vail et al., 1977). Additional data were obtained from the e-logs of nine oilindustry boreholes that sampled the sedimentary cover down to the substratum. A detailed micropaleontological study (Cravatte et al., 1974) compiles all the information on the biostratigraphy and depositional environments of the Miocene, Pliocene and Quaternary successions in four of the wells (Mistral1, Sirocco1, Autan1 and Tramontane1). The data from these wells were brought together in a compilation of the drilling reports (Guennoc et al., 2000). The Ecors programme (De Voogd et al., 1991) provided three general seismic sections across the entire margin, supplemented by a series of Expanding Spread Profiles giving estimates of the velocities (Pascal et al., 1993). Finally, we make use of the first results of the recent Sardinia project, which imaged the deep structure of the Gulf of Lions and Sardinian margins using wide-angle seismic data (Klingelhoefer et al., 2008; Gailler et al., 2009). 


\section{Configuration of the Gulf of Lions margin}

The peculiarity of the Gulf of Lions margin is its wide area of continental shelf, which contrasts with the narrow margins of Catalonia to the south-west and Provence to the northeast. Seismic reflection data tied to the boreholes (Fig. 1) have provided a detailed morphological map of the pre-Tertiary substratum (Fig. 2). In the present study, we first describe the morphology and superficial structures of the substratum, and then its deep structure using seismic refraction results (Pascal et al., 1993; Klingelhoefer et al., 2008; Gailler et al., 2009). Finally, we present the characteristics of the sedimentary cover and the areal extent of the synrift sediments.

\subsection{Morphology and faults}

Two distinct topographic regions can be recognized in the Gulf of Lions (Fig. 2): the elevated north-eastern sector, represented in cross-section on Fig. 3A, is characterized by narrow basins and marked topographic highs. The south-western sector, represented in cross-section on Fig. 3B, is characterized by a relatively smooth basement topography and a broad depression known as the "Graben Central". Within these sectors (Fig. 4), three generations of structural trends can be recognized which are inherited from the tectonic history. The NE-SW direction corresponds to faults inherited from the Variscan orogeny (Arthaud and Matte, 1977b). These major faults delimit the Tethyan palaeo-margin (Lemoine, 1984) and were reactivated during Pyrenean compression and at the end of the Miocene (Gorini et al., 1991; Mauffret et al., 2001; Gorini et al., 2005). Surprisingly, these faults were not significantly reactivated during the rifting except in the northern part of the Gulf of Lions and in the Camargue Basin, at the junction with the West European Rift system (see Chapter 5.2). The E-W to ENE-WSW directions characterize the north-eastern sector and its transition towards the deep basin. They are probably the result of a Mid-Cretaceous Pyrenean deformation in the prolongation of the North Pyrenean Fault Zone. These structures played a major role during 
rifting, as indicated by the presence of a major ENE-WSW fault, separating the proximal

199 margin, which is in a high topographic position, from the more subsident distal margin (Fig.

200 3A). The N-S directions (Fig. 4) characterize the Catalan margin and its conjugate Iglesiente 201 margin in its initial position before the opening of the basin (Fig. 5; Olivet, 1996). Many 202 studies (Gueguen et al., 1998; Gattacceca et al., 2007) support the hypothesis of a counter203 clockwise rotation (50-60 for Sardinia and 40-50 for Corsica during drifting).

204 Three structural domains can be highlighted extending from the coast to the oceanic crust 205 (Figs. 2 and 3). These three domains (I, II and III) are delimited by two major boundaries: B2 separates a sloping continental crust (in domains I and II) from the horizontal crust of domain III, while B1 is well represented in the north-eastern sector by ENE-WSW major faults (B1s) 208 which mark out a zone of tilted blocks (domain II, Fig. 3A) distinct from domain I. However, 209 in the south-western sector of the margin, this limit is unclear at the top of the crust (Fig. 3B). 210 The study of crustal thickness variations allows us to clarify the nature of these major 211 transitions at depth and identify three structural domains going from the land toward the basin 212 (Fig. 3). A first major transition in crustal thickness (the hinge zone) separates a relatively 213 undeformed continental crust (> $30 \mathrm{~km}$ thick) from domain I farther offshore, which is $\sim 100$ $214 \mathrm{~km}$ wide and characterized by a thinned continental crust ( $20 \mathrm{~km}$ thick). The seaward limit 215 of the hinge zone corresponds to the onset of increasingly thick sedimentary deposits toward 216 the basin. Still farther offshore, domain II is characterized by a considerable thinning of the 217 crust (from 20 to $5 \mathrm{~km})$ over a short distance $(\sim 50-70 \mathrm{~km})$. This domain coincides with the 218 tilted blocks zone observed at the top of the crust (between B1s and B2) in the north-eastern 219 part of the margin, and represents the second major transition in crustal thickness (between B1d and B2). Domains I and II taken together are termed the "continental crust slope" owing to its morphology (sloping toward the basin) and the presence of upper continental crust. The continental crust slope can thus be defined as a segment, seaward of the hinge zone, where the 
continental crust is thinned and slopes down towards the basin. Domain II is marked by a

224 prominent reflector (reflector T) easily recognized at depth (De Voogd et al., 1991). A seismic facies (with highly reflective and discontinuous reflections), which is recognized on domain I and interpreted as the lower continental crust, pinches out on this reflector. Domain III marks 227 the transition between the continental crust slope and the oceanic crust. This 100-km-wide 228 domain exhibits a very thin $(\sim 5 \mathrm{~km})$ crust of undetermined nature. Refraction data indicate 229 high velocities $(\sim 7.3-7.2 \mathrm{~km} / \mathrm{s})$ at its base, which are neither typical of a continental crust nor 230 of an oceanic crust (Pascal et al., 1993). The exact nature of this domain in the Gulf of Lions 231 is still the subject of intense debate. Recently, based on wide-angle seismic analysis, Gailler 232 et al. (2009) interpreted a high-velocity zone in this domain (Fig. 3B) either as representing 233 exhumed lower continental crust or a mixture of lower continental crust and upper mantle 234 material. In this study, we refer to domain III as "undetermined crust". It corresponds to the 235 Ocean-Continent Transition (OCT), i.e. the transition between thinned continental crust and 236 oceanic crust (Boillot et al., 1980).

237 The faults bounding the depressions of domain I display a small displacement during rifting. 238 For example, a horizontal extension of around $10 \mathrm{~km}$ has been calculated in the wider and 239 deeper Camargue basin (Séranne et al., 1995). Assuming an initial thickness of the continental 240 crust of between 30 and $40 \mathrm{~km}$ (Gailler et al., 2009), we can estimate the thinning factor B 241 related to domain I (Fig. 3). The factor calculated in this way, which lies between 1.5-2 for 242 domain I assuming uniform extension, induces a theoretically horizontal movement of 243 between 33 and $50 \mathrm{~km}$. In fact, we only observe 15-20 km of horizontal movement. Thus, we 244 can conclude that more than half of the thinning of domain I cannot be explained by upper 245 crustal extension. Conversely, the crustal configuration of domain II (tilted blocks) suggests a 246 large amount of crustal extension $(\beta=4.5-6)$ (Fig. 3). 
To summarize the crustal observations, a major contrast occurs between domain I and domain

248 II on the Gulf of Lions continental crust slope. Domain I is characterized by a thinned 249 continental crust and weak stretching. Domain II (tilted blocks zone) is characterized by a 250 strongly thinned continental crust and major stretching. These domains can be recognized by 251 their crustal thicknesses and are delimited by a major fault at the top of the crust (fig. 3). 252 These observations are in line with the "stretching paradox" (Bessis, 1986; Burrus, 1989) in 253 the Gulf of Lions (see Chapter 3.4). The study of the sedimentary cover backs up these 254 observations as shown in the following.

255

\subsection{The sedimentary cover}

The sedimentary cover of the Gulf of Lions displays a thickness up to $8 \mathrm{~km}$ in the basin and up to $5 \mathrm{~km}$ on the shelf (Fig. 3). This Oligocene to Recent succession is classically divided into four major units according to seismic and borehole data interpretations. The lowermost part the succession is made up of a synrift unit (in yellow on figures) which has been sampled onshore in the Camargue basin. Thick silty marl and evaporite-bearing Oligocene deposits have been described that are typical of a lagoonal lacustrine environment (Triat and Truc, 1983). Four wells have sampled the synrift unit offshore, but only in its upper part, so the total thickness of the synrift deposits remains uncertain. The corresponding seismic facies exhibits continuous to discontinuous reflectors. The second unit (Mi on figures), of Aquitanian to Tortonian age, is characterized by sedimentation on a wide prograding shelf. This unit fills pre-existing hollows in the relief, and displays morphologies with geometrical onlaps (Fig. 6) and progradations toward the basin, forming features that are clearly recognized not only on seismic data as clinoforms (between 80 and $100 \mathrm{~km}$ from the coast on Fig. 3B) but also on dipmeter data in the Autan 1 well (Cravatte et al., 1974). These facies are made up of deltaic deposits. The third unit (Me on figures), is restricted to the basin (Fig. 3), and corresponds to Messinian terrigeneous siliciclastic and evaporitic facies related to the major drawdown of sea 
274 level in the Mediterranean after its isolation from Atlantic waters (Hsü, 1972; Cita, 1973;

275 Clauzon, 1973; Ryan, 1973). A recent detailed description and new interpretation of this unit 276 can be found in Bache et al., 2009. The fourth unit (PQ on figures), of Pliocene to Quaternary 277 age, records the restoration of open marine conditions at its base passing up into an overall 278 regressive sequence (Cravatte et al., 1974) characterized by the reconstruction of shelf-slope 279 geometries with prograding clinoforms.

280 The first point that we emphasize here concerns the thickness of the synrift deposits. The 281 Gulf of Lions margin has been described as an extensive area with deep grabens formed 282 during the Oligocene by normal faults that have reactivated older fault trends (Bessis, 1986; 283 Gorini et al., 1991; Séranne et al., 1995; Guennoc et al., 2000). Here, we propose a new 284 interpretation based on the depositional pattern and the highly contrasted seismic facies of 285 pre-rift and syn-rift sediments. On seismic profiles, syn-rift sediments (drilled or identified at 286 the outlet of the Camargue Graben) show a relatively continuous seismic facies (Fig. 6). 287 Mesozoic (Jurassic) series drilled in the Calmar (Fig. 6) and Cicindelle boreholes display a 288 highly reflective and discontinuous seismic facies. Borehole data, seismic facies and 289 sedimentary geometries allow us to differentiate the pre-rift and syn-rift sediments. According 290 to our interpretation, supported by the analysis of a huge seismic dataset, it appears that synrift deposits are very thin on the Gulf of Lions margin ( $<1$ s TWTT, Fig. 4), except in some as areas such as the "Camargue" and the "Marseilles" basins where more than $2 \mathrm{~km}$ of 293 synrift sediments have been drilled (Benedicto et al., 1996; Guennoc et al., 2000). The highly 294 reflective and discontinuous seismic facies previously interpreted as syn-rift deposits in the 295 Gulf of Lions (Bessis, 1986; Gorini et al., 1991; Séranne et al., 1995; Guennoc et al., 2000) 296 corresponds in fact to older Mesozoic sediments ( $\mathrm{Mz}$ on figures). A smaller degree of 297 shortening in the Languedoc-Provence area than in the Pyrenees (see chapter on "Pyrenean 298 inheritance") could explain the preservation of Mesozoic basins in the Gulf of Lions. This 
new interpretation of synrift sediment thickness is in agreement with Steckler and Watts'

300 (1980) observations (see 3.4).

301 The second point concerns the presence of a major erosional surface at the top of the synrift 302 deposits or directly on the substratum. In the south-western part of the Gulf of Lions, this 303 surface erodes syn-rift deposits and is clearly distinguished from a more recent major erosion 304 surface (Fig. 7) attributed to the Messinian (Bache et al., 2009). In this part of the margin, the 305 Miocene shelf (Mi) is thick and preserved between the two surfaces (Fig. 7). In the elevated north-eastern part of the Gulf of Lions, the substratum is directly eroded. The GLP2 basement structure, located at the boundary between domain I and domain II, is eroded perpendicularly 308 to its main strike (Fig. 8), and thus demonstrates the importance of this erosion. Three major 309 axis of erosion can be outlined (in red on Figs. 2 and 4). In this part of the margin, there are 310 almost no Miocene deposits (Mi), so the two erosional surfaces are often merged. However, 311 two arguments lead us to link GLP2 substratum erosion to the early erosional phase identified 312 in the south-western part of the margin. (1) The first argument is based on paleogeography: no 313 Messinian fluvial network comparable to the Messinian Rhône, and capable of eroding the 314 GLP2 structure, has been found farther landward. However, we should not ignore the 315 presence of karst features comparable to those observed in Ardeche (Mocochain et al., 2006).

316 (2) The erosional surface also affects the top of the tilted blocks at the foot of the eroded 317 GLP2 high (Fig. 8). These blocks are overlain by Lower Miocene sediments (Mi) and were 318 therefore eroded and destabilized before the Messinian erosional event. To the East, the 319 margins of the Ligurian Sea are also cut by many canyons. These canyons were subaerial 320 during the Messinian crisis (Clauzon, 1978; Estocade-group, 1978; Ryan and Cita, 1978; 321 Savoye and Piper, 1991), and then re-eroded during the Quaternary (Cyaligure-group, 1979). An older formation of these features could also be considered. 
To summarize the sedimentary observations, the major part of the Gulf of Lions margin is highly eroded and synrift deposits are either very thin or completely lacking (domain II and seaward part of domain I). Landward of this early erosion, some significant but localised synrift accumulations can be picked out (in yellow on Fig. 2).

\section{Discussion}

Our study highlights the major characteristics of the Gulf of Lions continental crust slope (see 5.1). Two major domains can be differentiated by their crustal structures and sedimentary configurations (Figs. 2 and 3). Domain I is characterized by a thinned but weakly stretched upper crust. This domain is characterized in its landward part by significant synrift accumulations, and, in its seaward part, by early erosion affecting the top of thin synrift deposits or cutting down directly into the substratum. Domain II, on the contrary, is characterized by extremely thinned and stretched crust that can also be affected by the early erosion. These domains can be recognized by their crustal thicknesses, and are sometimes delimited by a major fault at the top of the crust. This configuration leads us to discuss the following points.

\subsection{A high topographic position of the continental crust slope during rifting}

The strong early erosion observed at the top of the synrift deposits or directly on the substratum suggests that the erosion took place under subaerial conditions. In addition, the generally thin development of synrift sediments (Fig. 4) suggests either that the margin did not subside much during rifting or that it was uplifted at the end of rifting. The aggrading shelf-slope geometries during the early to middle Miocene (Fig. 3B) indicate that the morphology of the margin and the subsidence pattern changed after this early erosion and led to the creation of accommodation. The micropaleontological study of borehole samples from this Miocene shelf (Cravatte et al., 1974) reveals a deepening of the depositional environment 
at this time. We can conclude that a large part of the Gulf of Lions margin subsided slowly during rifting and rapidly after rifting, leading to the deposition of thick post-rift Miocene to Quaternary deposits. Therefore, it appears that the synrift subsidence calculated by Bessis (1986) and Burrus (1989) is excessive due to the overestimated thickness of synrift deposits. Because of this, we reach the same conclusion as Steckler and Watts (1980): mechanisms other than passive heating due to stretching are required to account fully for these observations.

Figure 9 shows our view of the margin configuration at the end of rifting. We interpret the tilted blocks zone (strongly thinned and stretched domain II) as corresponding to the main rift 360 (40-50 km wide, comparable with present-day width of the Rhine and East African rifts). The 361 seaward part of domain I (characterized by early erosion), separated from the tilted blocks 362 zone by a major fault, is interpreted as a rift flank uplifted and eroded during rifting. The same configuration can be assumed in the Ligurian domain, where numerous canyons have 364 been described (see 5.2). In the Gulf of Lions and Sardinia, some grabens with synrift 365 deposits are observed flanking the rift shoulder (in yellow on Fig. 9), while no synrift deposits 366 have been identified in the main rift (domain II). A deflection of drainage systems away from 367 the main rift and into the continental interior can be suggested to explain this configuration. 368 The same pattern has been observed in the Red Sea (Frostick and Reid, 1989.), where it is 369 proposed as a possible mechanism explaining why the central parts of the Red Sea are 370 underfilled despite the massive evaporite precipitation following the major phase of extension 371 during the early Miocene (Bosence, 1998). After rifting, the entire Gulf of Lions margin was 372 affected by strong postrift subsidence and thick sedimentary accumulations. Polyphase compressional deformation, which seems to be a common feature in the post-rift evolution of many passive margins and rifts (Cloetingh et al., 2008), has not been observed here. 


\subsection{Zonation of stretching}

The transition between the thinned but poorly stretched domain I and the extremely thinned and stretched domain II is characterized by a major fault identified near the surface. The main stretching phase of the crust is thus localized in the narrow domain II, seaward of this major fault. The "necking zone" described on numerous margins has been similarly interpreted (Sibuet, 1992; Lavier and Manatschal, 2006; Reston, 2007; Péron-Pinvidic and Manatschal, 2008). Domain I did not subside much during rifting and is characterized by a significant thinning of the crust which cannot be explained by the stretching of the upper crust (see 5.1). We can highlight a zonation of stretching between domains I and II, delimited by a major fault. Moreover, a seismic facies interpreted as the lower continental crust pinches out on the rising of the $\mathrm{T}$ reflector from domain I to domain II (Fig. 3). These observations are incompatible with uniform extension, but are in better agreement with a larger extension at depth than in the upper crust (Royden and Keen, 1980; Steckler, 1985; Steckler et al., 1988; Davis and Kusznir, 2004; Reston, 2007; Huismans and Beaumont, 2008). Other observations compatible with a depth-dependant stretching model can be found in the South Atlantic (Contrucci et al., 2004; Moulin et al., 2005; Dupré et al., 2007; Aslanian et al., 2009), Australia (Driscoll and Karner, 1998) as well as the Central and North Atlantic (Davis and Kusznir, 2004; Funck et al., 2004; Labails et al., 2009).

\subsection{Segmentation of the margin}

The Provencal Basin is characterized by a segmentation of the order of 100-150 km (Fig. 1). The wide Gulf of Lions-Sardinia segment is flanked on either side by the narrow ProvenceNurra and Catalonian-Iglesiente segments. The Sardinia and Corsica blocks cannot be dissociated to reduce the width of Gulf of Lions-Sardinia segment (Fig. 5) because of the presence of a Permian dyke complex between Sardinia and Corsica (Arthaud and Matte, 1977a). Such a configuration poses a problem for kinematic reconstructions if we assume that 
404 the thinning is directly linked to horizontal stretching. The same question arises for the 405 reconstruction of the Newfoundland and Iberian margins bordering the Atlantic, where the 406 independent movement of different blocks has been suggested. For example, (Sibuet et al., 407 2007) have proposed the movement of Flemish Cap and Orphan Knoll in relation to the Great 408 Bank or the movement of Galicia Bank in relation to the Iberian margin. A segmentation of 409 the same order has been observed on the American and African conjugate margins, but the 410 movement of independent blocks seem unlikely (see (Sahabi et al., 2004) for a review). 411 Because of the young age of the Western Mediterranean, it is possible to study the 412 segmentation in more detail here than in old and complex margins. Our results suggest that 413 the segmentation observed in the Provencal Basin is linked to processes of thinning rather 414 than horizontal extension.

415

416

417

418

419

420

\subsection{A new model of evolution for the Gulf of Lions}

Observations in the Gulf of Lions are taken into account here to propose a model for the formation of this crustal segment (Fig. 10). At first, most of the Gulf of Lions margin is subaerially exposed during an early phase of rifting (Fig. 10A). A major fault separates the 40-50 km wide rift from domain I, which represents the uplifted footwall of this fault. The seaward part of domain I (GLP2 structure) is subject to continuous erosion. Drainage is directed away from the rift to external basins (in yellow). In a second stage (Fig. 10B), the main break up occurs between the Gulf of Lions and Sardinia. This major stretching phase is restricted to domain II (tilted blocks zone). During this stage, domain I remains at a high topographic position despite significant thinning. From this stage onwards, the formation of undetermined crust (domain III) is accompanied by a general subsidence of the margin. An inversion of the drainage network occurs towards the centre of the basin, associated with thick accumulations of postrift sediments. The last stage corresponds to the formation of typical 
oceanic crust at the centre of the basin with sea-floor spreading (Fig. 10C). The different

431 morphological domains of the margin are summarized on Fig. 10.

432

433

434

435

436

437

\section{Conclusion}

The crustal structure and sedimentary facies of the Gulf of Lions margin allows us to highlight two different domains on the continental crust slope (previously considered as a single wide rift domain). A major fault differentiates a thinned and stretched narrow rift domain (domain II, tilted blocks zone) from a thinned and poorly stretched domain (domain I). This latter domain is characterized by a deficit of subsidence during rifting. The identification of domain I provides a new insight into the formation of the Gulf of Lions margin. The zonation of stretching and subsidence is accompanied by a 100-150 km segmentation of the Provencal Basin, which suggests processes of thinning rather than simple horizontal extension.

Numerous examples of thinned domains with limited subsidence during rifting have been described on the "continental crust slope" of several Atlantic-type passive margins (Moulin et al., 2005; Dupré et al., 2007; Péron-Pinvidic and Manatschal, 2008; Aslanian et al., 2009; Labails et al., 2009). The evolution proposed here for the Gulf of Lions (located in a particular geodynamic context) could be generalized to the formation of rifted continental margins irrespective of their geodynamic context. This hypothesis could be further tested by thermo-mechanical models and give mechanical constraints on the complex interplay between subduction and roll-back processes in extensional basin formation (Cloetingh et al., 1995).

Different mechanisms have been proposed to explain rift flank uplift on extensional margins landward of the hinge zone, including thermal processes (Royden and Keen, 1980; Keen, 1985; Steckler, 1985; Buck, 1986) and flexural isostatic rebound in response to mechanical unloading of the lithosphere during extension (Watts, 1982; Weissel and Karner, 1989; Gilchrist and Summerfield, 1990; Kooi et al., 1992; Ten Brink and Stern, 1992; Van Der 
Beek and Cloetingh, 1992). In the Gulf of Lions, we find that the rift shoulder is located

seaward of the hinge zone (in a thinned domain). This domain remains in a high topographic position during rifting and then undergoes strong subsidence. Our observations provide new data to constrain these physical models.

\section{ACKNOWLEDGMENTS}

This work was funded by CNRS, IFREMER (F.B. scholarship) and the Action Marges research programme. We thank Total for making their data available and in particular Jean Loup Rubino and Jacqueline Camy-Peyret for their valuable help in working with the database. We acknowledge the EPSL editor, Rob D. van der Hilst and journal reviewers for advice and comments on the manuscript. We would also like to thank Laurent Jolivet and Sylvie Leroy for their thoughtful comments. M.S.N. Carpenter post-edited the English style.

\section{REFERENCES CITED}

Arthaud, F., and Matte, P., 1977a. Détermination de la position initiale de la Corse et de la Sardaigne à la fin de l'orogenèse hercynienne grâce aux marqueurs géologiques antémésozoïques. Bull. Soc. géol. Fr. 7, 833-840.

Arthaud, F., and Matte, P., 1977b. Late Paleozoic strike-slip faulting in Southern Europe and Northern Africa: result of a right lateral shear zone between the Appalachians and the Urals. Bull. Soc. geol. Amer. 88, 1305-1320.

Arthaud, F., and Séguret, M., 1981. Les structures pyrénéennes du Languedoc et du Golfe du Lion (Sud de la France). Bull. Soc. géol. Fr. 23, 51-63.

Aslanian, D., Moulin, M., Olivet, J. L., Unternehr, P., Bache, F., Contrucci, I., Klingelhoefer, F., Labails, C., Matias, L., Nouzé, H., and Rabineau, M., 2009. Brazilian and African Passive Margins of the Central Segment of the South Atlantic Ocean: Kinematic constraints. Tectonophysics. 468, 98-112.

Auzende, J. M., Bonnin, J., and Olivet, J. L., 1973. The origin of the Western Mediterranean basin. J. Geol. Soc. Lond. 19, 607-620.

Bache, F., Olivet, J. L., Gorini, C., Rabineau, M., Baztan, J., Aslanian, D., and Suc, J. P., 2009. The Messinian Erosional and Salinity Crises: View from the Provence Basin (Gulf of Lions, Western Mediterranean). Earth Planet. Sci. Lett. 286, 139-157.

Bellaiche, G., Rehault, J. P., Vanney, J. R., Auzende, J. M., Courmes, F., Irr, F., and Roure, F., 1979. Plongées en submersible dans les canyons méditerranéens: principaux résultats de la campagne Cyaligure. Bull. Soc. géol. Fr. 21, 533-543.

Benedicto, A., Labaume, P., Séguret, M., and Séranne, M., 1996. Low-angle crustal ramp and basin geometry in the Gulf of Lion passive margin: the Oligocene-Aquitanian Vistrenque graben, SE France. Tectonics. 15, 1192-1212.

Bessis, F., 1986. Some remarks on the study of subsidence of sedimentary basins. Application to the Gulf of Lions margin (Western Mediterranean). Mar. Pet. Geol. 3, 37-63. 
Boccaletti, M., and Guazzone, G., 1974. Remnant arcs and marginal basins in the Cainozoic development of the Mediterranean. Nature. 252, 18-21.

Boillot, G., Grimaud, S., Mauffret, A., Mougenot, A., Kornprobst, J., Mergoil-Daniel, J., and Torrent, G., 1980. Ocean-continent boundary off the Iberian margin: serpentinite diapir west of the Galicia Bank. Earth Planet. Sci. Lett. 48, 23-34.

Bosence, D. W. J., 1998. Stratigraphic and sedimentological models of rift basins, in: Purser, B. H., and Bosence, D. W. J., (Eds.), Sedimentation and tectonics of rift basins: Red Sea-Gulf of Aden., Chapman and Hall, London.

Buck, R., 1986. Small-scale convection induced by passive rifting: the cause for uplift of rift shoulders. Earth Planet. Sci. Lett. 77, 362-372.

Burrus, J., 1989. Review of geodynamic models for extensional basins; the paradox of stretching in the Gulf of Lions (northwest Mediterranean). Bull. Soc. géol. Fr. 8, 377393.

Cita, M. B., 1973. Mediterranean evaporite: paleontological arguments for a deep-basin desiccation model, in: Drooger, C. W., (Ed.), Messinian events in the Mediterranean, North-Holland Publ. Co, Amsterdam, pp. 206-228.

Clauzon, G., 1973. The eustatic hypothesis and the pre-Pliocene cutting of the Rhône valley, in: Ryan, W. B. F., Hsü, K. J., and al., (Eds.), Initial Reports of Deep Sea Drilling Project, Volume 13, (U.S. Government Printing Office), Washington, pp. 1251-1256.

Clauzon, G., 1978. The Messinian Var canyon (Provence, Southern France) Paleogeographic implications. Mar. Geol. 27, 231-246.

Cloetingh, S., Beekman, F., Ziegler, P. A., Van Wees, J. D., and Sokoutis, D., 2008. Post-rift compressional reactivation potential of passive margins and extensional basins. Geological Society, London, Special Publications. 306, 27-70.

Cloetingh, S., Van Wees, J. D., Van Der Beek, P. A., and Spadini, G., 1995. Role of pre-rift rheology in kinematics of extensional basin formation: constraints from thermomechanical models of Mediterranean and intracratonic basins. Mar. Pet. Geol. $12,793-807$.

Contrucci, I., Matias, L., Moulin, M., Geli, L., Klingelhofer, F., Nouze, H., Aslanian, D., Olivet, J. L., Rehault, J. P., and Sibuet, J. C., 2004. Deep structure of the West African continental margin (Congo, Zaire, Angola), between 5 degrees S and 8 degrees S, from reflection/refraction seismics and gravity data. Geophys. J. Int. 158, 529-553.

Cravatte, J., Dufaure, P., Prim, M., and Rouaix, S., 1974, Les sondages du Golfe du Lion: Stratigraphie, Sédimentologie, Notes et Mémoires $n^{\circ} 11$, Paris, Compagnie Française des Pétroles, p. 209-274.

Cyaligure-group, 1979. Plongées en submersible dans les canyons méditerranéens: principaux résultats de la campagne CYALIGURE. Bull. Soc. géol. Fr. 21, 533-543.

Davis, M., and Kusznir, N. J., 2004. Depth-dependent lithospheric stretching at rifted continental margins, in: Karner, G. D., (Ed.), Proceedings of National Science Foundation Rifted Margins Theoretical Institute, Columbia University Press, New York, pp. 92-136.

De Voogd, B., Nicolich, R., Olivet, J. L., Fanucci, F., Burrus, J., Mauffret, A., Pascal, G., Argnani, A., Auzende, J. M., Bernabini, M., Bois, C., Carmignani, L., Fabbri, A., Finetti, I., Galdeano, A., Gorini, C. Y., Labaume, P., Lajat, D., Patriat, P., Pinet, B., Ravat, J., Ricci Luchi, F., and Vernassa, S., 1991. First deep seismic reflection transect from the Gulf of Lions to Sardinia (ECORS-CROP profiles in Western Mediterranean), in: Meissner, R., Brown, L., Durbaum, H.-J., Fuchs, K., and Seifert, F., (Eds.), Continental lithosphere: Deep seismic reflections. v. Geodynamics, 22, American Geophysical Union, Washington, pp. 265-274. 
Dewey, J. F., Pittman, W. C., Ryan, W. B. F., and Bonin, J., 1973. Plate tectonics and the evolution of the Alpine system. Geol. Soc. Am. Bull. 84, 3137-3180.

Driscoll, N. W., and Karner, G. D., 1998. Lower crustal extension across the Northern Carnavon basin, Australia: Evidence for an eastward dipping detachment. J. Geophys. Res. 103, 4975-4992.

Dupré, S., Bertotti, G., and Cloetingh, S., 2007. Tectonic history along the South Gabon Basin: Anomalous early post-rift subsidence. Mar. Pet. Geol. 24, 151-172.

Edel, J. B., 1980. Etude paléomagnétique en Sardaigne. Conséquences pour la géodynamique de la Méditerranée occidentale, Thèse de l'Institut de Physique du Globe. Université Louis Pasteur, Strasbourg, 310 p.

Estocade-group, 1978. Messinian subaerial erosion of the Stoechades and Saint Tropez canyons - a submersible study. Mar. Geol. 27, 247-269.

Faccenna, C., Funiciella, F., Giardini, D., and Lucente, P., 2001. Episodic back-arc extension during restricted mantle convection in the Central Mediterranean. Earth Planet. Sci. Lett. 187, 105-116.

Ferrandini, J., Gattacceca, J., Ferrandini, M., Deino, A., and Janin, M.-C., 2003. Chronostratigraphie et paléomagnétisme des dépôts oligo-miocènes de Corse: implications géodynamiques pour l'ouverture du bassin liguro-provençal. Bull. Soc. géol. Fr. 174, 357-371.

Frostick, L., and Reid, I., 1989. Is structure the main control of river drainage and sedimentation in rifts? J. Afr. Earth. Sci. 8, 165-182.

Funck, T., Jackson, H. R., Louden, K. E., Dehler, S. A., and Wu, Y., 2004. Crustal structure of the northern Nova Scotia rifted continental margin (eastern Canada). J. Geophys. Res. 109.

Gailler, A., Klingelhoefer, F., Olivet, J. L., Aslanian, D., and Sardinia-group., 2009. Crustal structure of a young margin pair: new results across the Liguro-Provencal Basin from wide-angle seismic tomography. Earth Planet. Sci. Lett. 236, 333-345.

Gattacceca, J., Deino, A., Rizzo, R., Jones, D. S., Henry, B., Beaudoin, B., and Vadeboin, F., 2007. Miocene rotation of Sardinia:New paleomagnetic and geochronological constraints and geodynamic implications. Earth Planet. Sci. Lett. 258, 359-377.

Gennessaux, M., Auzende, J. M., and Olivet, J. L., 1974. Les orientations structurales et magnétiques sous-marines au sud de la Corse et la dérive corso-sarde. C.R. Acad. Sci., Paris. 278, 2003-2006.

Gilchrist, A. R., and Summerfield, M. A., 1990. Differential denudation and flexural isostasy in formation of rifted-margin upwarps. Nature. 346, 739-742.

Gorini, C., Le Marrec, A., and Mauffret, A., 1993. Contribution to the structural and sedimentary history of the Gulf of Lions (Western Mediterranean) from the ECORS profiles, industrial seismic profiles and well data. Bull. Soc. géol. Fr. 164, 353-363.

Gorini, C., Lofi, J., Duvail, C., Dos Reis, T., Guennoc, P., Le Strat, P., and Mauffret, A., 2005. The Late Messinian salinity crisis and Late Miocene tectonism: interaction and consequences on the physiography and post-rift evolution of the Gulf of Lions margin. Mar. Pet. Geol. 22, 695-712.

Gorini, C., Viallard, P., and Déramond, J., 1991. Modèle d'inversion structurale négative: la tectonique extensive post-nappe du fossé de Narbonne-Sigean (Corbières, Sud de la France). C.R. Acad. Sci., Paris. 312, 1013-1019.

Gueguen, E., Doglioni, C., and Fernandez, M., 1998. On the post-25 Ma geodynamic evolution of the western Mediterranean. Tectonophysics. 298, 259-269.

Guennoc, P., Gorini, C., and Mauffret, A., 2000. Histoire géologique du Golfe du Lion et cartographie du rift oligo-aquitanien et de la surface messinienne. Géologie de la France. 3, 67-97. 
Guieu, G., and Roussel, J., 1990. Arguments for the pre-rift uplift and rift propagation in the Ligurian-Provençal basin (Northwestern Mediterranean) in the light of Pyrenean Provençal orogeny. Tectonics. 9, 1113-1142.

Hsü, K. J., 1972. When the Mediterranean dried up. Sci. Am. 227, 44-51.

Huismans, R., and Beaumont, C., 2008. Complex rifted continental margins explained by dynamical models of depth-dependent lithospheric extension. Geology. 36, 163-166.

IOC, IHO, and BODC, 2003. Centenary Edition of the GEBCO Digital Atlas, published on CD-ROM on behalf of the Intergovernmental Oceanographic Commission and the International Hydrographic Organization as part of the General Bathymetric Chart of the Oceans, British Oceanographic Data Centre, Liverpool, U.K.

Jolivet, L., Augier, R., Faccenna, C., Negro, F., Rimmele, G., Agard, P., Robin, C., Rossetti, F., and Crespo-Blanc, A., 2008. Subduction, convergence and the mode of backarc extension in the Mediterranean region. Bull. Soc. géol. Fr. 179, 525-550.

Jolivet, L., and Faccenna, C., 2000. Mediterranean extension and the Africa-Eurasia collision. Tectonics. 19, 1095-1106.

Keen, M. J., 1985. The dynamics of rifting: deformation of the lithosphere by active and passive driving forces. Geophysical Journal of the Royal Astronomical Society. 80, 95-120.

Klingelhoefer, F., Olivet, J. L., Aslanian, D., Bache, F., Moulin, M., Matias, L., Afilhado, A., Nouzé, H., Beslier, M. O., and Gailler, A., 2008. Preliminary results from the Sardinia deep seismic cruise on the Western Sardinia and Gulf of Lions conjugate margin pair. EGU General Assembly, Vienna.

Kooi, H., Cloetingh, S., and Burrus, J., 1992. Lithospheric necking and regional isostasy at extensional basins 1 . Subsidence and gravity modeling with an application to the Gulf of Lions Margin (SE France). J. Geophys. Res. 97, 17553-17571.

Labails, C., Olivet, J. L., and Dakhla.study.group, 2009. Crustal structure of the SW Moroccan margin from wide-angle and reflection seismic data (the Dakhla experiment). Part B - The tectonic heritage. Tectonophysics. 468, 83-97.

Lavier, L., and Manatschal, G., 2006. A mechanism to thin the continental lithosphere at magma-poor margins. Nature. 440, 324-328.

Le Douaran, S., Burrus, J., and Avedik, F., 1984. Deep-structure of the North-Western Mediterranean basin: Results of a two-ship seismic survey. Mar. Geol. 55, 325-345.

Lemoine, M., 1984. La marge occidentale de la Thétys ligure, Les marges continentales actuelles et fossiles autour de la France, Masson, Paris, pp. 155-248.

Malinverno, A., and Ryan, W. B. F., 1986. Extension in the Tyrrhenian Sea and shortening in the Apennines as a result of arc migration driven by the sinking of the lithosphere. Tectonics. 5, 227-245.

Mauffret, A., Durand de Grossouvre, B., Dos Reis, A. T., Gorini, C., and Nercessian, A., 2001. Structural geometry in the eastern Pyrenees and western Gulf of Lion (Western Mediterranean). Journal of Structural Geology. 23, 1701-1726.

McKenzie, D. P., 1978. Some remarks on the development of sedimentary basins. Earth Planet. Sci. Lett. 40, 25-32.

Mocochain, L., Clauzon, G., and Bigot, J. Y., 2006. The Ardeche endokarstic responses to the eustatic variations resulting from the Messinian salinity crisis. Bull. Soc. géol. Fr. 177, 27-36.

Moulin, M., Aslanian, D., Olivet, J. L., Contrucci, I., Matias, L., Géli, L., Klingelhoefer, F., Nouzé, H., Réhault, J. P., and Unternehr, P., 2005. Geological constraints on the evolution of the Angolan margin based on reflection and refraction seismic data (Zaïango project). Geophys. J. Int. 162, 793-810. 
Olivet, J. L., 1996. La Cinématique de la plaque Ibérique, Bulletin des Centres de Recherches Exploration-Production Elf Aquitaine. v. 20, Pau, France, pp. 131-195.

Pascal, G. P., Mauffret, A., and Patriat, P., 1993. The ocean-continent boundary in the Gulf of Lion from analysis of expanding spread profiles and gravity modelling. Geophys. J. Int. 113, 701-726.

Péron-Pinvidic, G., and Manatschal, G., 2008. The final rifting evolution at deep magma-poor passive margins from Iberia-Newfoundland: a new point of view. Int. J. Earth Sci. doi:10.1007/s00531-008-0337-9.

Réhault, J. P., Boillot, G., and Mauffret, A., 1984. The western Mediterranean Basin geological evolution. Mar. Geol. 55, 447-477.

Reston, T., 2007. Extension discrepancy at North Atlantic nonvolcanic rifted margins: depthdependant stretching or unrecognized faulting? Geology. 35, 367-370.

Roure, F., Choukroune, P., Berastegui, X., Munoz, J. A., Villien, A., Matheron, P., Bareyt, M., Seguret, M., Camara, P., and Deramond, J., 1989. ECORS deep seismic data and balanced cross sections: geometric constraints on the evolution of the Pyrenees. Tectonics. 8, 41-50.

Royden, L., and Keen, C. E., 1980. Rifting process and thermal evolution of the continental margin of eastern Canada determined from subsidence curves. Earth Planet. Sci. Lett. 51, 343-361.

Ryan, W. B. F., 1973. Geodynamic implications of the Messinian crisis of salinity, in: Drooger, D. W., (Ed.), Messinian events in the Mediterranean, Elsevier, Amsterdam, pp. 26-38.

Ryan, W. B. F., 1976. Quantitative evaluation of the depth of the Western Mediterranean before, during and after the Messinian salinity crisis. Sedimentology. 23, 791-813.

Ryan, W. B. F., and Cita, M. B., 1978. The nature and distribution of Messinian erosional surface-indication of a several kilometer-deep Mediterranean in the Miocene. Mar. Geol. 27, 193-230.

Sahabi, M., Aslanian, D., and Olivet, J. L., 2004. A new starting point for the history of the central Atlantic. C. R. Geoscience. 336, 1041-1052.

Savoye, B., and Piper, D. J. W., 1991. The Messinian event on the margin of the Mediterranean Sea in the Nice area, southern France. Mar. Geol. 97, 279-304.

Séranne, M., 1999. The Gulf of Lion continental margin (NW Mediterranean) revisited by IBS: an overview, in: Durand, B., Jolivet, L., Horváth, F., and Séranne, M., (Eds.), The Mediterranean Basins: Tertiary extension within the Alpine Orogen. v. Special Publication 156, The Geological Society, London, pp. 15-36.

Séranne, M., Benedicto, A., Labaume, P., Truffet, C., and Pascal, G., 1995. Structural style and evolution of the Gulf of Lion Oligo-Miocene rifting: role of the Pyrenean orogeny. Mar. Pet. Geol. 12, 809-820.

Sibuet, J.-C., 1992. Formation of non-volcanic passive margins: a composite model applies to the conjugate Galicia and southeastern Flemish cap margins. Geophys. Res. Lett. 19, 769-772.

Sibuet, J. C., and Collette, B. J., 1991. Triple junctions of Bay of Biscay and North Atlantic; new constraints on the kinematic evolution. Geology. 19, 522-525.

Sibuet, J. C., Srivastava, S. P., Enachescu, M., and Karner, G. D., 2007. Early Cretaceous motion of Flemish Cap with respect to North America: implications on the formation of Orphan Basin and SE Flemish Cap-Galicia Bank conjugate margins, in: Karner, G. D., Manatschal, G., and Pinheiro, L. M., (Eds.), Imaging, Mapping and Modelling Continental Lithosphere Extension and Breakup. v. 282, Geological Society, London, Special Publications, pp. 63-76. 
Smith, A. G., 1971. Alpine deformation and the oceanic areas of the Tethys, Mediterranean and Atlantic. Geol. Soc. Am. Bull. 82, 2039-2070.

Steckler, M., Watts, A. B., and Thorne, J. A., 1988. Subsidence and basin modeling at the U.S. Atlantic passive margin, in: Sheridan, R. E., and Grow, J. A., (Eds.), The Atlantic Continental Margin: U.S. v. The Geology of Noth America, V1-2, Geological Society of America, pp. 399-416.

Steckler, M. S., 1985. Uplift and extension at the Gulf of Suez: indications of induced mantle convection. Nature. 317, 135-139.

Steckler, M. S., and Watts, A. B., 1980. The Gulf of Lion: subsidence of a young continental margin. Nature. 287, 425-429.

Ten Brink, U. S., and Stern, T., 1992. Rift flank uplifts and hinterland basins: comparison of the Transantartic Mountains with the Great Escarpment of Southern Africa. J. Geophys. Res. 97, 569-585.

Triat, J. M., and Truc, G., 1983. Le rôle des failles N50 dans la sédimentation des temps méso et cénozoïques et dans l'évolution tectonique du bassin de Sud-Est (France). Bull. Cent. Rech. Explor. -Prod. Elf Aquitaine. 7, 425-432.

Vail, P. R., Mitchum, R. M., Todd, R. G., Widmier, J. M., Thompson, S., Sangree, J. B., Bubb, J. N., and Hatlelid, W. G., 1977. Seismic stratigraphy and global changes of sea-level. Seismic Stratigraphy - Applications to hydrocarbon exploration. v. Memoir 26. American Association of Petroleum Geologists, Tulsa, 49-212 p.

Van Der Beek, P. A., and Cloetingh, S., 1992. Lithospheric flexure and the tectonic evolution of the Betic Cordilleras (SE Spain). Tectonophysics. 203, 325-344.

Watts, A. B., 1981. The U. S. Atlantic continental margin: subsidence history, crustal structure and thermal evolution. Geology of passive continental margins: history, structure, and sedimentologic record (with special emphasis on the Atlantic margins). American Association of Petroleum Geologists, Education Course Note Series, No. 19., p. 2/1-2/75.

Watts, A. B., 1982. Tectonic subsidence, flexure and global changes in sea-level. Nature. 297, 469-474.

Weissel, J. K., and Karner, G. D., 1984. Thermally-induced uplift of the southeast highlands of Australia. EOS. 65, 1115.

Weissel, J. K., and Karner, G. D., 1989. Flexural uplift of rift flanks due to mechanical unloading of the lithosphere during extension. J. Geophys. Res. 94, 13919-13950.

Yamasaki, T., and Stephenson, R., 2008. Change in tectonic force inferred from basin subsidence: implication for the dynamical aspects of back-arc rifting in the western Mediterranean. Earth Planet. Sci. Lett. 277, 174-183.

Ziegler, P. A., and Cloetingh, S., 2004. Dynamic processes controlling evolution of rifted basins. Earth-Sci. Rev. 64, 1-50.

\section{FIGURE CAPTIONS}

Figure 1: Topographic and bathymetric map of the West European Rift system and the

Provencal Basin (IOC et al., 2003), along with data base used for this study (detail inset). The

Provencal Basin was created by counterclockwise rotation of Corsica-Sardinia micro-plate during the Miocene (see flowlines). Typical oceanic crust is shown at the centre of the basin. 
Along its north-western edge, the Gulf of Lions margin is bracketed by the narrow Provence

741 and Catalonian margins. The Gulf of Lions represents a 150-km wide segment. GOL. Gulf of

742 Lions, P. Provence Margin, C. Catalonian Margin, N. Nurra Margin, S. Sardinian Margin, I.

743 Igleziente Margin, L. Languedoc, Pr. Provence. Boreholes: Ci. Cicindelle, Si. Sirocco, Ca.

744 Calmar, Mi. Mistral, Am. Agde Maritime, Tr. Tramontane, Ra. Rascasse, Au1. Autan 1,

745 GLP2. Golfe du Lions Profond 2.

Figure 2: Morphological map of the pre-Tertiary substratum (depth in TWTT s) in the Gulf of

Lions. The north-eastern sector is characterized by narrow basins and marked topographic

highs. The south-western sector exhibits fewer topographic highs, but is characterized by a broad depression known as the "Graben Central". Domains I, II and III are delimited by two major boundaries extending across the entire Gulf of Lions. B2 separates a sloping continental crust (domains I and II) from the horizontal crust of domain III. B1 is characterized by a ENE-WSW-trending major fault at the top of the crust (B1s) and/or by the onset of a major transition in crustal thickness at depth (B1d). Three major axes are indicated (in red) showing areas where the substratum is directly affected by early erosion. Synrift deposits with a thickness of more than $0.5 \mathrm{~s}$ TWTT are mainly located landward of these axes of erosion. CB: Camargue Basin. MB: Marseilles Basin.

Figure 3: (A) Line drawings of the ECORS profile (north-eastern sector) and (B) LRM16Ligo20 profiles (south-western sector) converted into $\mathrm{km}$ (velocities indicated in $\mathrm{km} / \mathrm{s}$ from

761 Pascal et al, 1993 and from Gailler et al, 2009, location of the base of the crust from 762 Klingelhoefer et al., 2008). The continental crust slope (domains I and II) is affected by the 763 early erosion (in red). Domain I is characterized by a thinned continental crust and weak 764 stretching, in contrast to domain II (hachured) characterized by a strongly thinned continental 
crust and major stretching (tilted blocks zone). Location of profiles on Fig. 2. PQ: Pliocene-

Quaternary. Me: Messinian. Mi: Miocene. Mz: Mesozoic.

Figure 4: Isopach map of synrift sediments. Synrift deposits are very thin on the Gulf of Lions margin $(<1 \mathrm{~s}$ TWTT), except for some areas such as the "Camargue" and "Marseilles" basins where more than $2 \mathrm{~km}$ of synrift sediments have been drilled. Three structural directions can be distinguished using topographic highs (NE-SW, ENE-WSW and N-S).

Figure 5: Position of the Corsica-Sardinia micro-plate before the opening of the basin (slightly modified after Olivet, 1996). The Gulf of Lions-Sardinia segment is wider than the Provence-Nurra and Catalonian-Iglesiente segments. The Sardinian-Corsica block cannot be dissociated from the reconstruction to reduce (as much as the other segments) the width of the Gulf of Lions-Sardinia segment, because of the presence of a Permian dyke complex between Sardinia and Corsica (Arthaud and Matte, 1977a). However, in this position, we can pick out a 50-km wide domain on all the segments (including domain II of the Gulf of Lions), which is

780 bordered by major faults. Domain I in the Gulf of Lions and its conjugate domain on the 781 Sardinia margin thus represent a "distinctive feature" in comparison with the other segments.

Figure 6: Seismic profile showing the highly reflective and discontinuous seismic facies interpreted in this study as Mesozoic substratum. Location of profiles and boreholes on Fig. 4. PQ: Pliocene-Quaternary. Mi: Miocene. Mz: Mesozoic.

Figure 7: Seismic profile showing effects of early erosion (erosional truncations) at the top of synrift deposits in the south-western sector of the margin. Location of profiles on Fig. 4. PQ: 
791 Figure 8: Seismic profiles showing a major axis of early erosion affecting the substratum of 792 the elevated north-eastern sector of the margin. The GLP2 basement structure is eroded 793 perpendicularly to the main strike direction, and thus reveals the importance of this erosion. 794 Location of profiles on Fig. 4. PQ: Pliocene-Quaternary. Me: Messinian. Mi: Miocene.

796 Figure 9: Palaeogeographic map of the Provencal-Ligurian rift. The tilted blocks zone 797 (strongly thinned and stretched domain II) is interpreted as the main rift (40-50 km wide). The

798

Figure 10: Model of evolution of the Gulf of Lions margin. A. Early rifting. The major part of the Gulf of Lions margin was subaerially exposed during an early phase of rifting. Domain I is separated from the $40-50 \mathrm{~km}$ wide rift by a major fault, and represents the uplifted footwall of this fault. B. Break-up. This major stretching phase is restricted to domain II (tilted blocks). At this time, domain I remains at a high topographic position despite the significant thinning. Subsequently, the initial stages of formation of undetermined crust (domain III) are accompanied by a general subsidence of the margin (subsidence phase). C. Present-day configuration, after the formation of typical oceanic crust at the centre of the basin, associated with sea-floor spreading (drifting phase). 


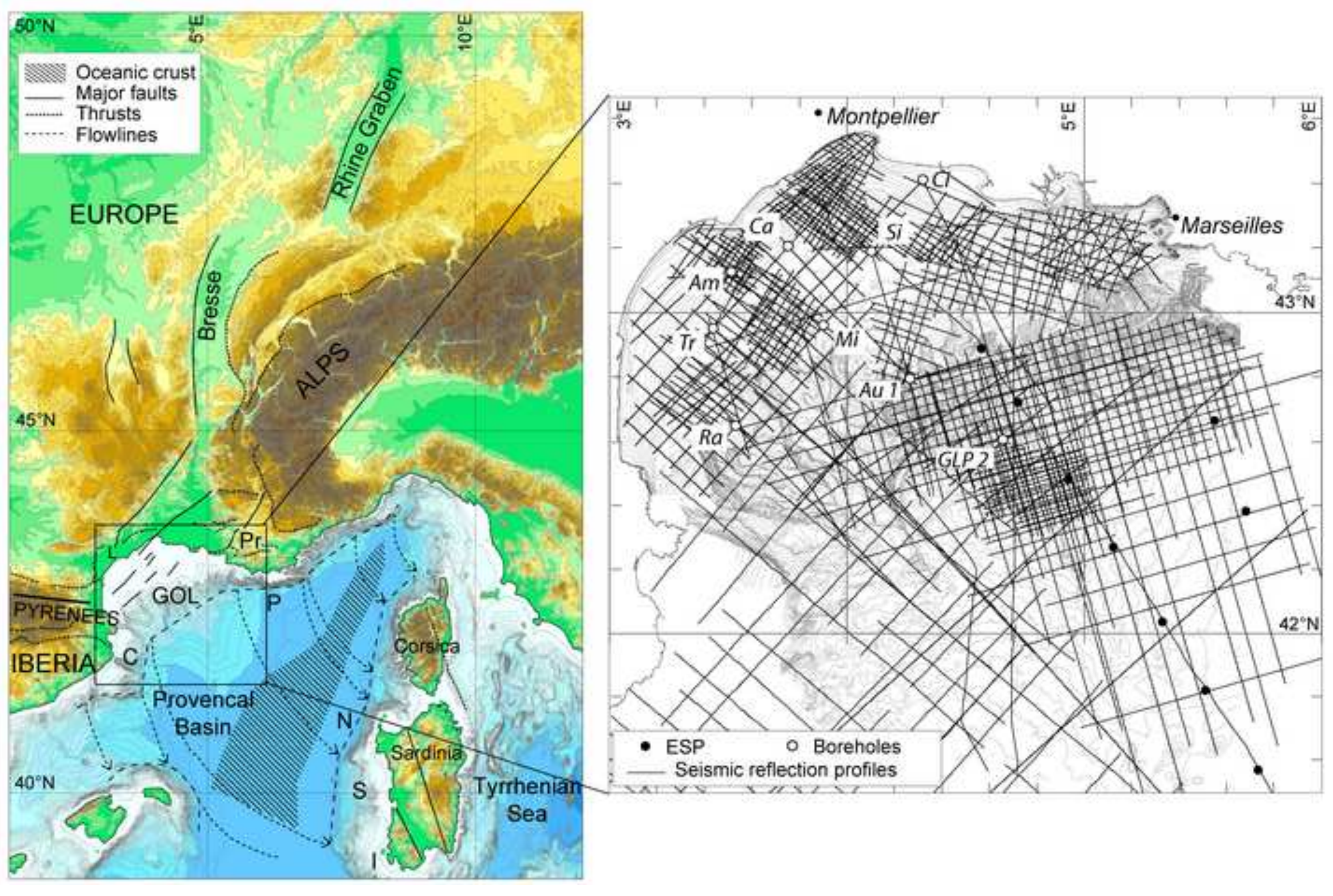

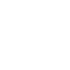




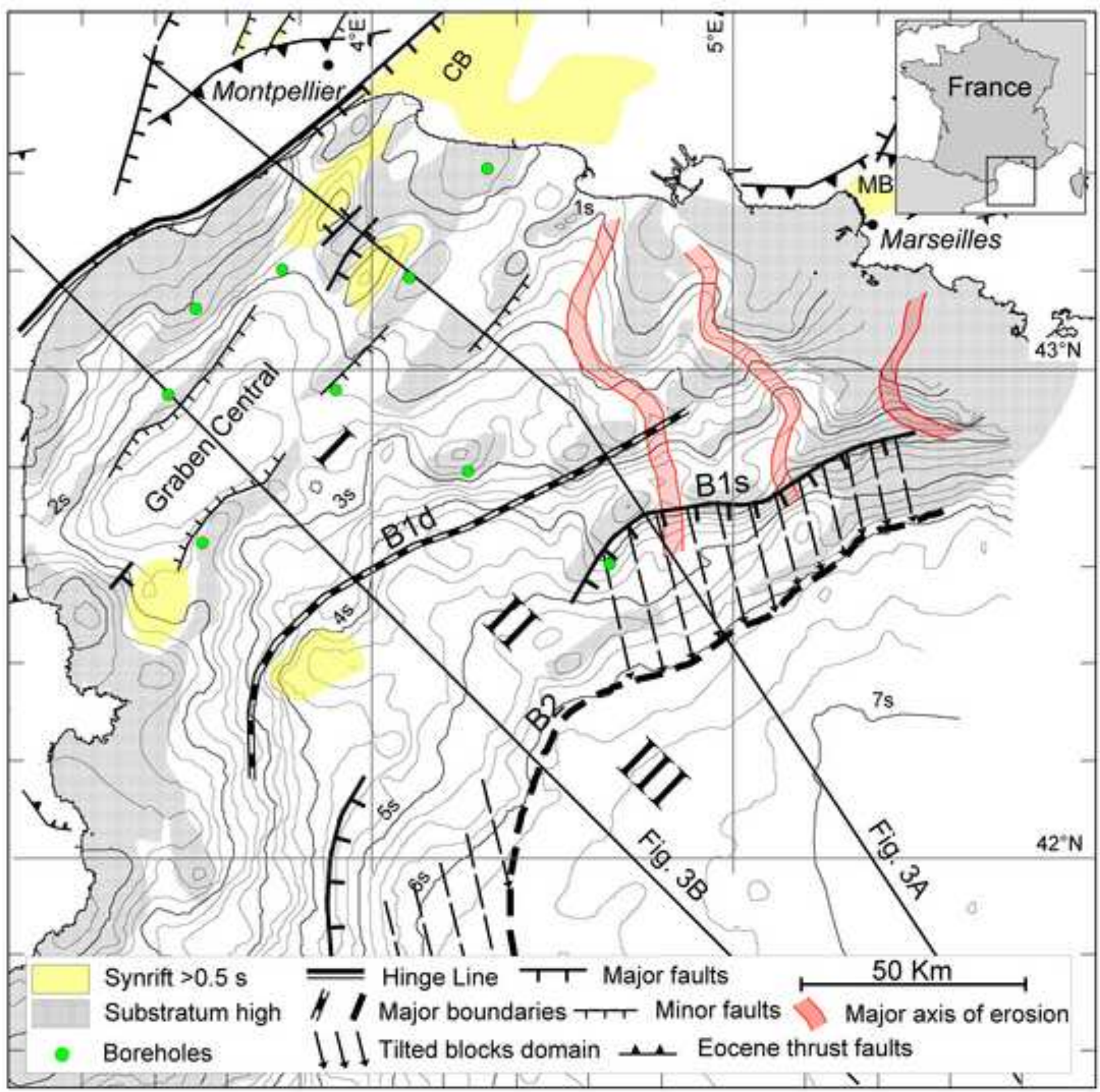




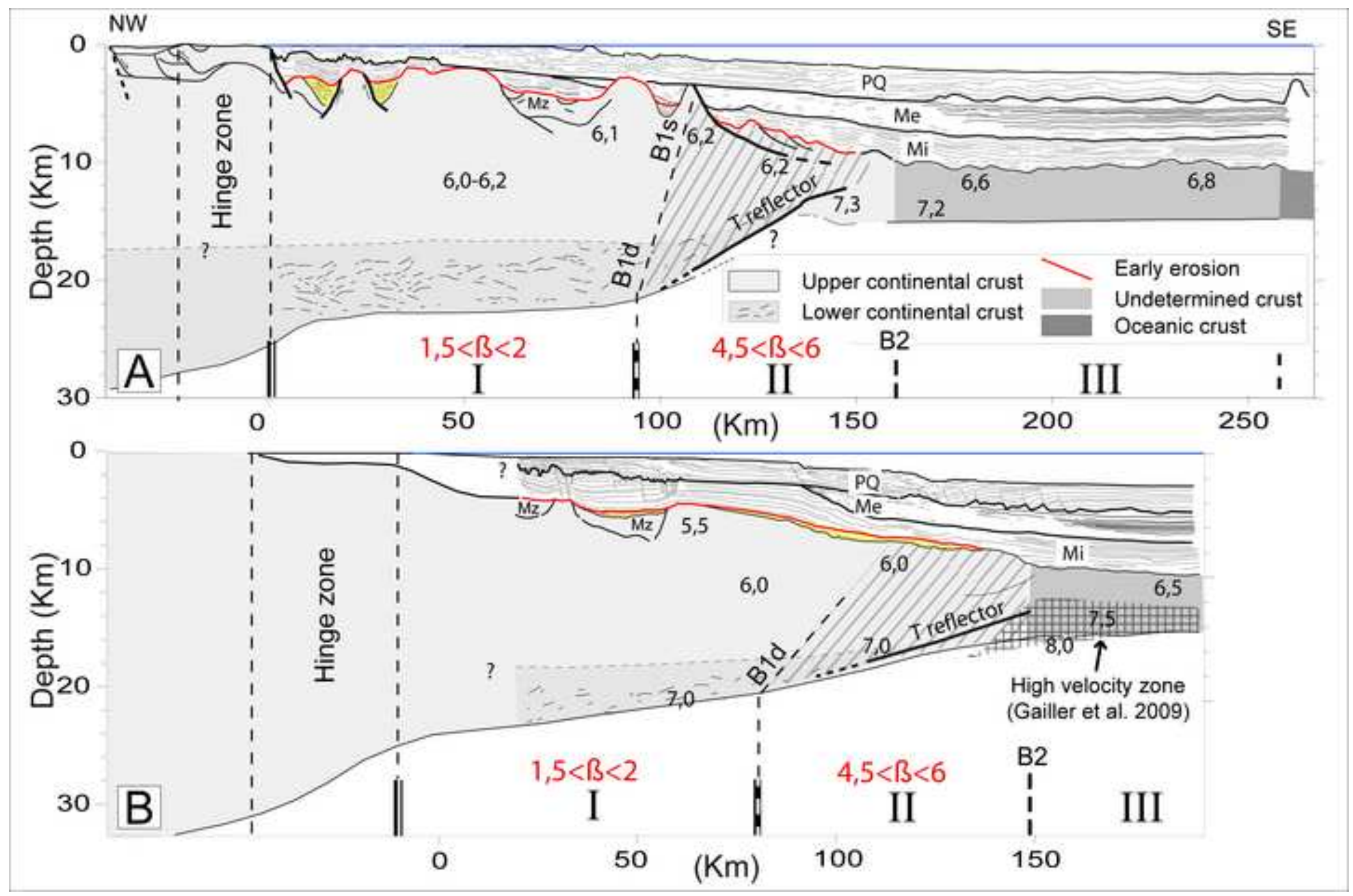




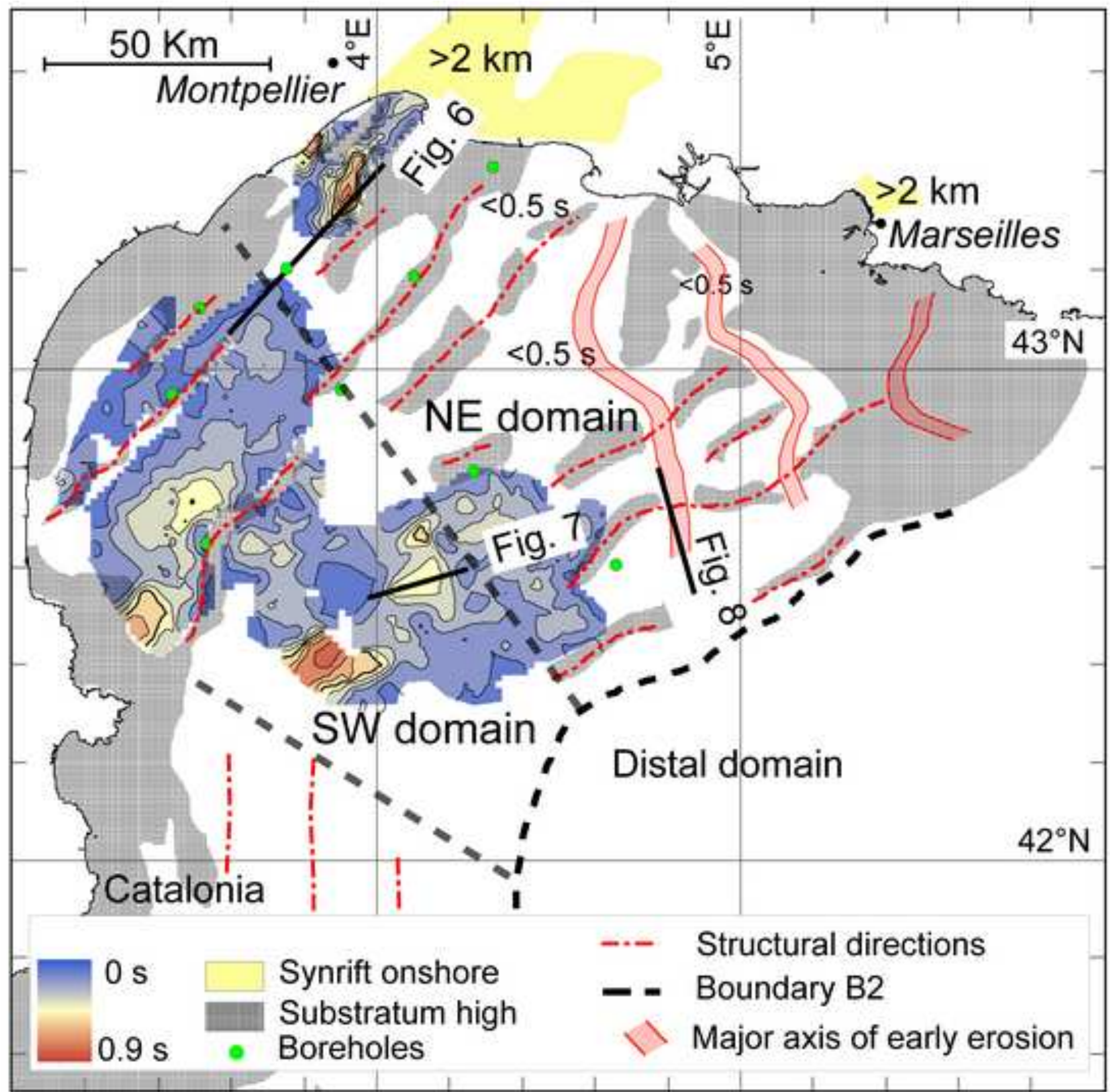




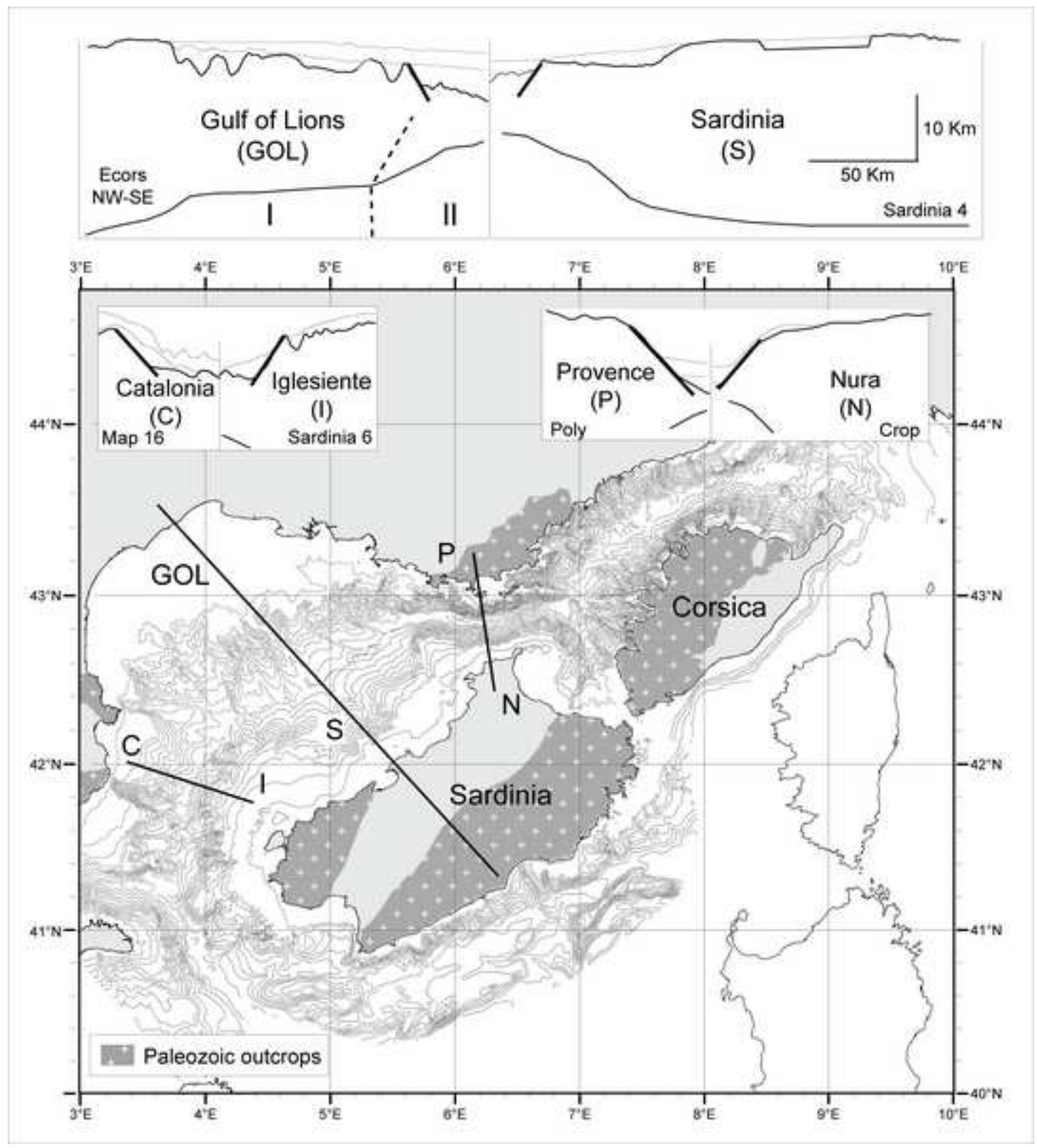


Click here to download high resolution image

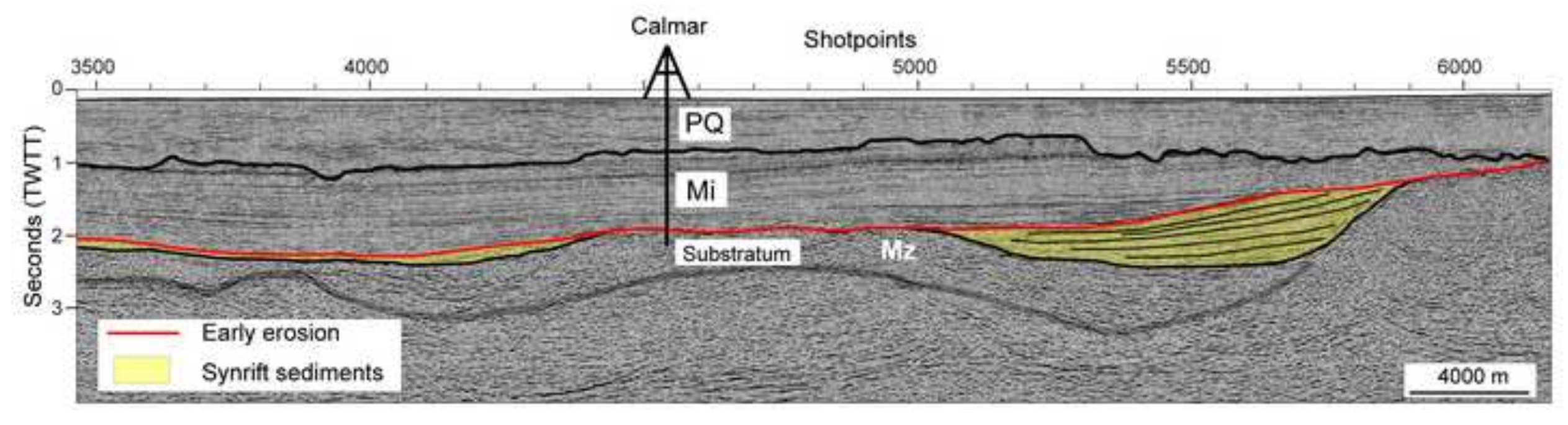




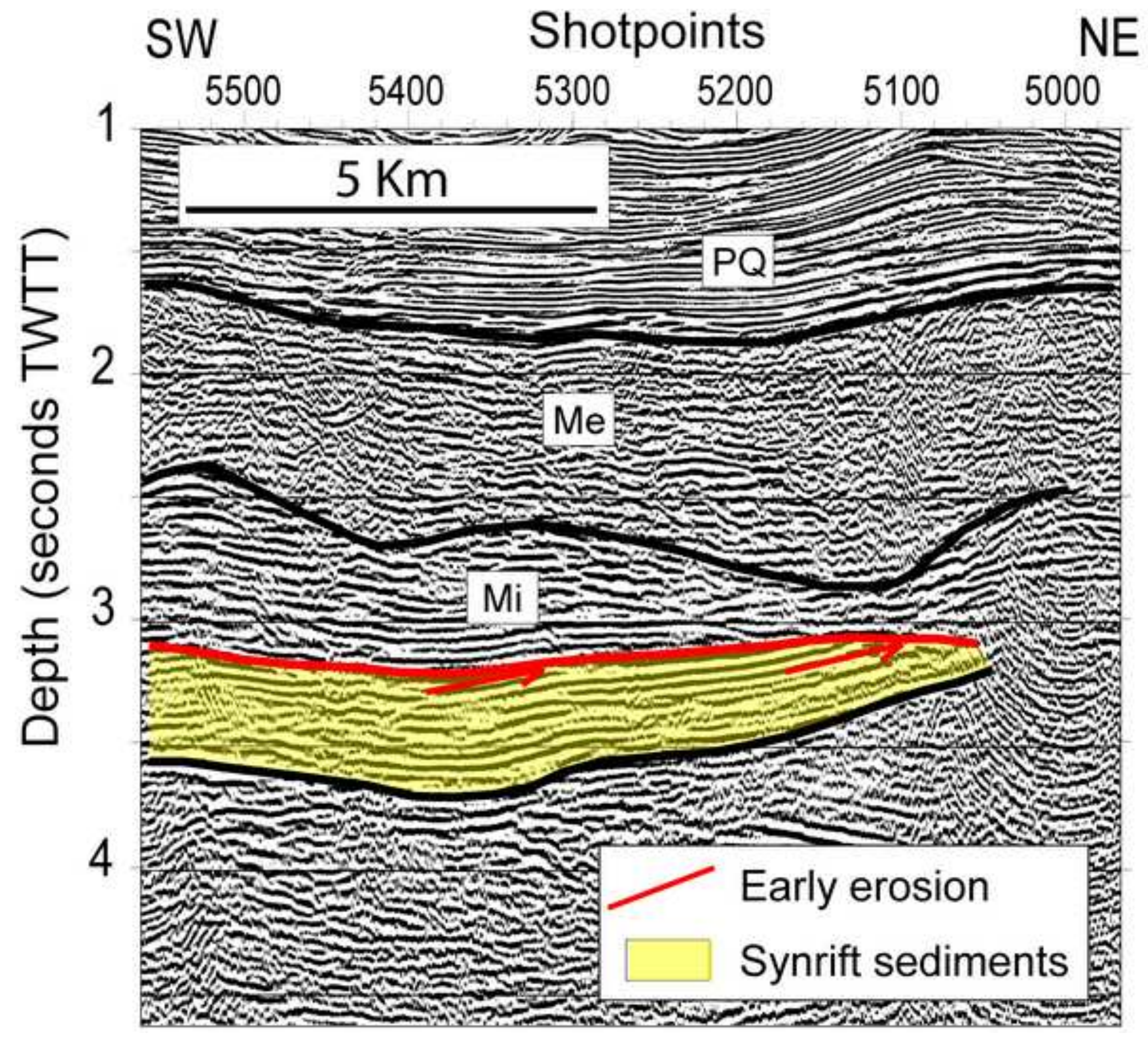


Click here to download high resolution image

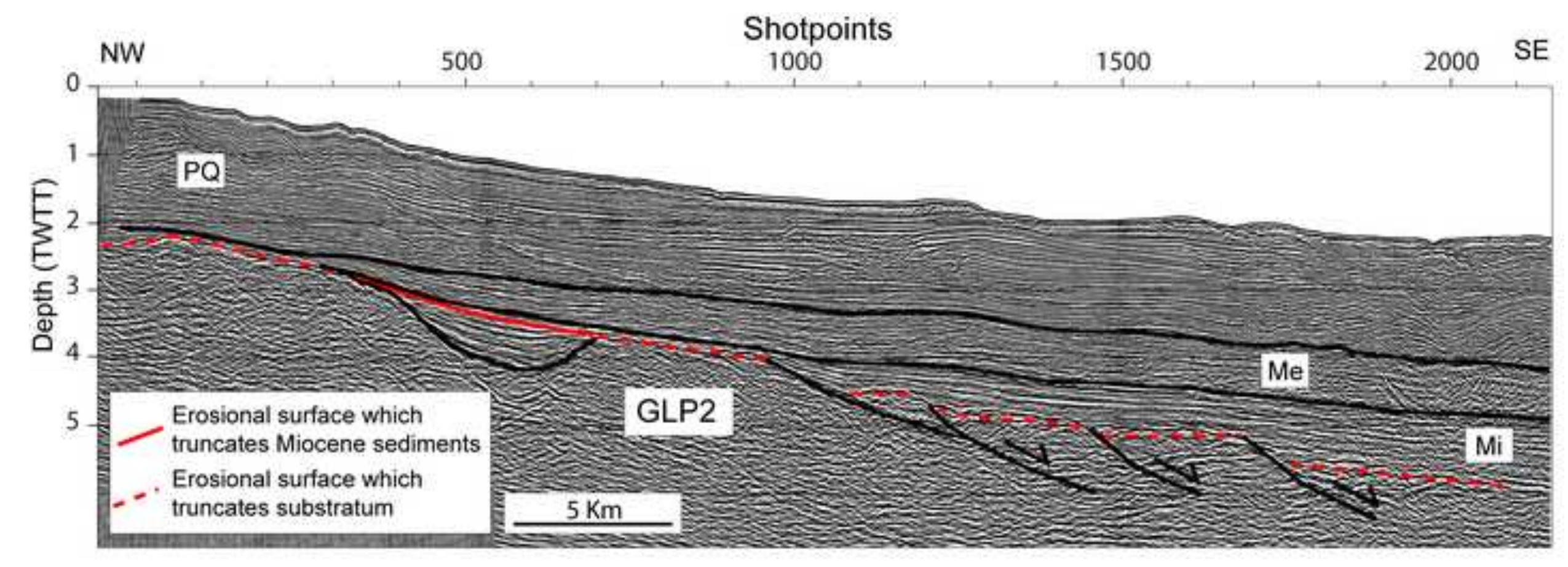

resolution image 


\section{Figureg}

Click here to download high resolution image

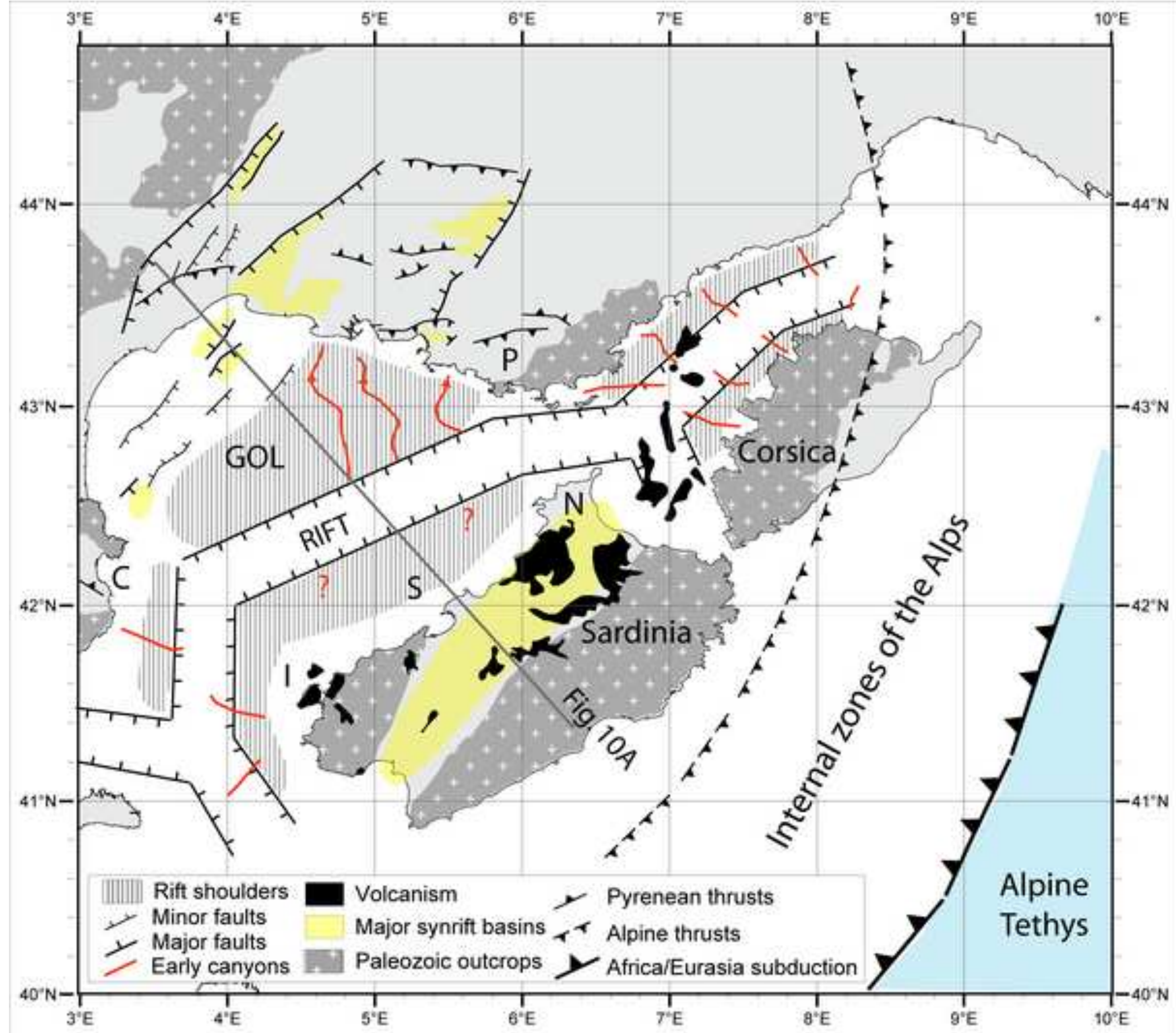




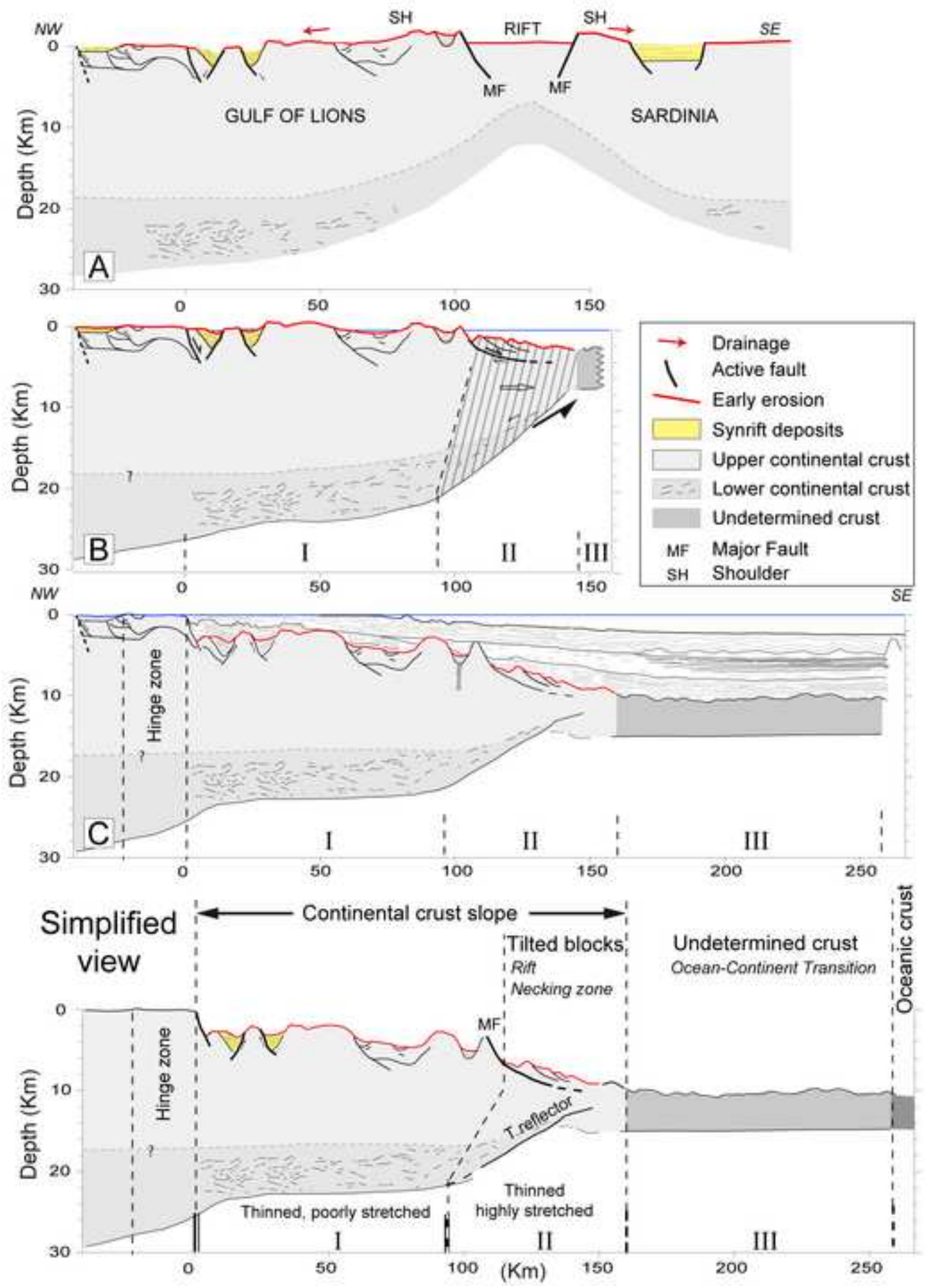

